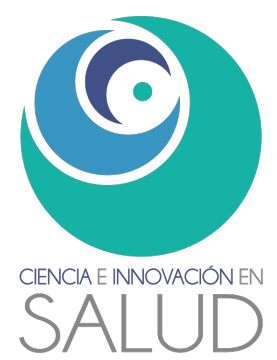

SALUD

\title{
Cervical ectopic pregnancy with colic abdominal pain
}

\section{Embarazo ectópico cervical con dolor abdominal tipo cólico}

\author{
Leyla Kuzmar ${ }^{1}$, Jaime Jordan ${ }^{1}$ \\ ${ }^{1}$ Clínica Saludcoop, Neiva, Colombia.
}

Submitted 02 Oct 2017 Accepted 19 Oct 2017 Published 11 Dec 2017

\section{Editor in chief}

Isaac Kuzmar,

editor@revcis.com

\section{Academic editor Guillermo Ashton}

\section{Corresponding author} Leyla Kuzmar,

leylakuzmar@yahoo.com

\section{DOI 10.17081/}

innosa.4.2.2852

CC) Copyright 2017 Kuzmar \& Jordan.

\section{Distributed under} Creative Commons CCBY 4.0

\section{OPEN ACCESS}

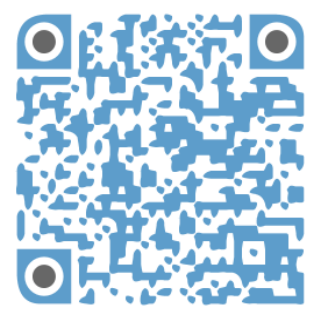

\section{ABSTRACT}

Background: Very few case reports of ectopic cervical pregnancy with clear photos are available in the scientific world literature. Is a leading cause of maternal morbidity and mortality with a pregnancy-related mortality. Cervical pregnancy is more common in pregnancies achieved after assisted reproductive technologies; it occurs in $0.1 \%$ of in vitro fertilization pregnancies. The potential morbidity demonstrates the importance of early diagnosis of a cervical ectopic so as early intervention and treatment may be employed. The most common symptom of cervical pregnancy is vaginal bleeding, which is often painless. Case report: A 39 year old woman, G4 P2 C1 A0 L3, two spontaneous vaginal deliveries and last child birth by caesarean section + Pomeroy 15 years back, who underwent three embryo transfer 6.1 weeks ago; referred to the obstetric emergency department with 8 days increasing colic abdominal pain with some vaginal bleeding.

Discussion: This is an interesting case report with few bleeding and increasing colic abdominal pain that did not answer to methrotexate and required a hysterectomy as the most viable solution.

\section{RESUMEN}

Introducción: Muy pocos reportes de casos de embarazo ectópico cervical con fotos claras están disponibles en la literatura científica mundial. Es una de las principales causas de morbilidad y mortalidad materna, relacionada con mortalidad del embarazo. El embarazo cervical es más frecuente en los embarazos logrados después de las técnicas de reproducción asistida; y ocurre en $0.1 \%$ de embarazos de fecundación in vitro. La morbilidad potencial demuestra la importancia de realizar un diagnóstico precoz de un embarazo ectópico cervical y con esto, emplear intervenciones y tratamientos tempranos. El síntoma más común del embarazo cervical es el sangrado vaginal, que a menudo es indoloro.

Caso Clínico: Una mujer de 39 años, G4 P2 C1 A0 V3, dos partos vaginales espontáneos y el último parto por cesárea + Pomeroy 15 años atrás, quién fué sometida a tres transferencias de embriones hace 6.1 semanas; remitida al servicio de urgencias obstétricas con 8 días de aumento de dolor abdominal tipo cólico con algo de sangrado vaginal.

Discusion: Este es un reporte de caso interesante con poco sangrado y un aumento del dolor abdominal tipo cólico que no respondió al metotrexate y requiriendo una histerectomía como la solución más viable.

Keywords: Cervical pregnancy; ectopic pregnancy; hysterectomy.

Palabras clave: Embarazo cervical; embarazo ectópico; histerectomía. 


\section{INTRODUCTION}

The rate of ectopic pregnancy declined from $2.0 \%$ in 2001 to $1.6 \%$ (Perkins, Boulet, Kissin, Jameison, 2015) in 2011 but is a leading cause of maternal morbidity and mortality with a pregnancy-related mortality of 31.9 deaths per 100,000 pregnancies (Grimes, 2006). Ectopic pregnancy incidence after assisted reproductive technology has decreased over time, but factors such as multiple embryo transfer increase the risk of ectopic pregnancy (Perkins et.al, 2015), representing a $2.4 \%$ ratio of ectopic pregnancies following fresh in vitro fertilization embryo transfers, while $7.6 \%$ following frozen-thawed embryo transfers (Pyrgiotis, Sultan, Neal, Hung-Ching, Grifo, Rosenwaks, 1994).

Cervical pregnancy is an extremely rare of non-tubal ectopic pregnancy in which the pregnancy products are implanted the lining of the endocervical canal, accounting for less than $1 \%$ of all ectopic gestations, with an estimated incidence of one in 2500 to one in 18,000 (Singh, 2013). C ervical pregnancy is more common in pregnancies achieved after assisted reproductive technologies; it occurs in $0.1 \%$ of in vitro fertilization pregnancies (Stratoudakis, Zygouris, Kastrinakis,Daskalakis, Panagopoulos, 2015). In some cases obesity is a risk factor for early pregnancy loss (Fedorcsák, Storeng, Dale, Tanbo, Abyholm T, 2000) and regularity of menstrual cycles does not affect an obesity treatment (Kuzmar, Cortés, Rizo, 2014). The potential morbidity demonstrates the importance of early diagnosis of a cervical ectopic so as early intervention and treatment may be employed.

\section{CASE REPORT}

A 39 year old woman, G4 P2 C1 A0 L3, two spontaneous vaginal deliveries and last child birth by caesarean section + Pomeroy 15 years back, who underwent three embryo transfer 6.1 weeks ago; referred to the obstetric emergency department with 8 days increasing colic abdominal pain with some vaginal bleeding. When the patient admitted, negative Blumberg sign, gynecological examination revealed a uterus in AVF with mild bimanual palpation pain, cervix of a multipara, closed orifice and no active bleeding, 2 days before B-HCG serum level was 23193 Mlu/ML, transvaginal ultrasonography revealed a large hypoechoic lesion at the level of the segment outside the endometrial cavity suggestive of $30 \mathrm{~mm}$ gestational sac with $12 \mathrm{~mm}$ doubtful of embryo with no heart rate. Her vital signs were: $\mathrm{BP}=110 / 70 \mathrm{~mm} \mathrm{Hg}, \mathrm{PR}=76$ per minute, Temp: $36^{\circ} \mathrm{C}$, New B-HCG: 31277 Mlu/ML. The medical and obstetric history of the patient was clear and the patient was hemodynamically stable. The use of chemotherapeutic agents (methotrexate) was decided. After the third dose of methotrexate the patient had a marked decrease in abdominal pain. New transvaginal ultrasound showed a gestational sac in the cervical segment with $6.4 \mathrm{w}$ asystolic embryo. Medical management failed with methrotexate because the new levels of BhGC were almost the same (32677 Mlu/ML) and no transvaginal ultrasonography changes, so after 6 days it is decided to do a total abdominal hysterectomy as the only surgical treatment alternative (Figure 1 and Figure 2) with secondary sterility authorized by the patient. Postsurgery without complications, patient in good clinical condition to be discharged. 


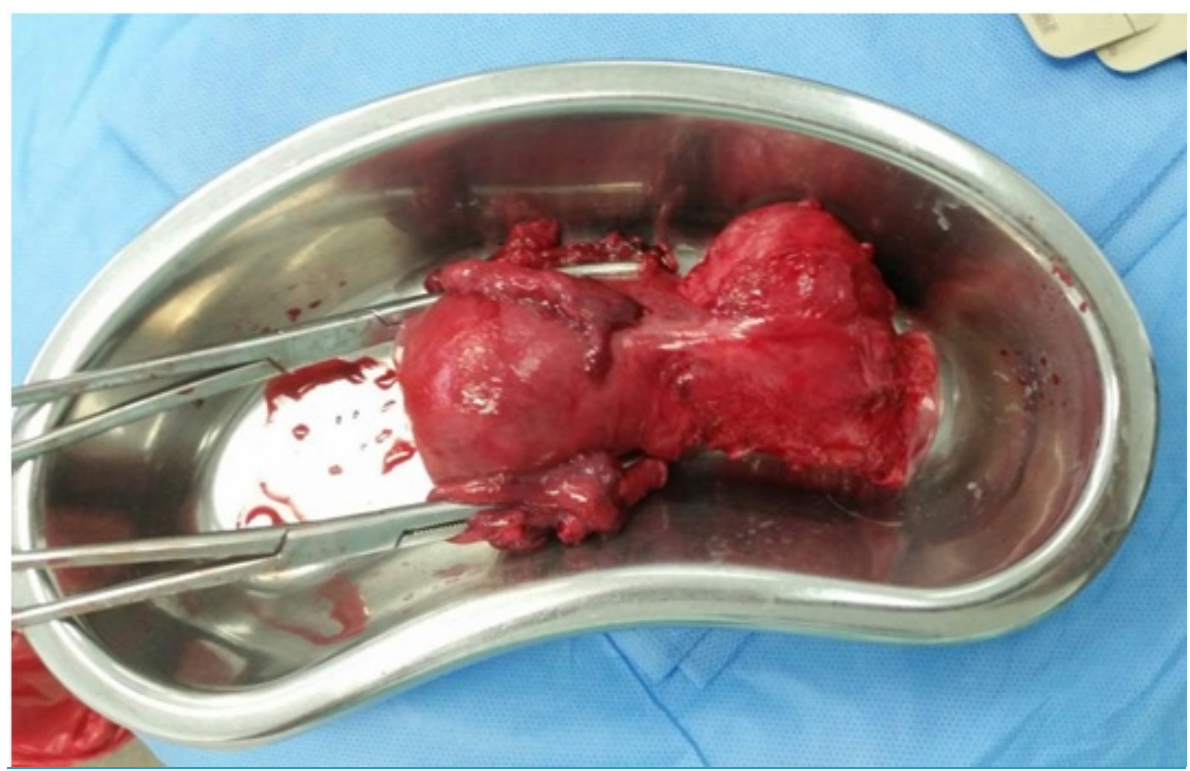

Figure 1. A specimen of uterus cut open in cervical region showing gestational sac attached to the wall of the cervix.

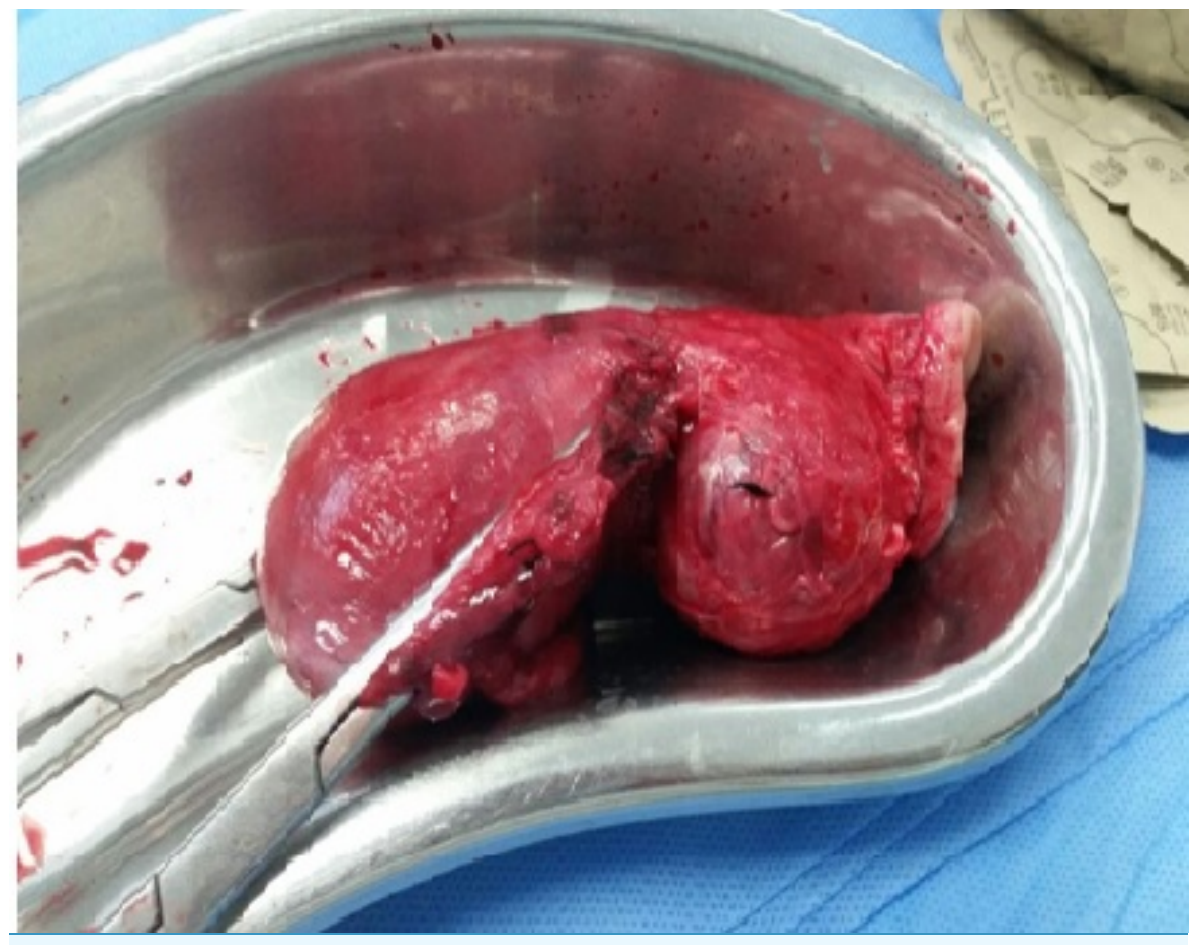

Figure 2. A specimen of uterus cut open in cervical region showing gestational sac attached to the wall of the cervix.

\section{DISCUSSION}

The most common symptom of cervical pregnancy is vaginal bleeding, which is often painless. On gynecological examination, the external OS may be open, with fetal membranes or pregnancy tissue. The diagnosis of cervical pregnancy is based on transvaginal ultrasound findings. 
empty uterus and the presence of gestational sac below the level of uterine arteries are the most important findings, whereas a barrel-shaped cervix and blood flow around the gestation sac may also be found (Hofmann, Urdl, Höfler, Hönigl, Tamussino, 1987).

Common pre-disposing risk factors for this rare ectopic pregnancy are a prior dilatation and curettage, most commonly done for termination of pregnancy, prior caesarean section and in vitro fertilisation (Sharma, Ojha, Mondal, Chattopadhyay, Sengupta, 2013).

Clinical diagnosis is difficult, but the application of first-trimester transvaginal ultrasonography has led to improvements in the early diagnosis of cervical pregnancy, thereby assisting in conservative and fertility-preserving treatment (Raskin, 1978).

The treatment options for a cervical pregnancy depend on the hemodynamic condition of the patient. For haemodynamically stable patient, conservative treatment like; a systemic or local methotrexate chemotherapy alone or combined with adjuvant methods such as subsequent cervical curettage or cervical tamponade, or intracervical potassium chloride injection, appears to be a convenient and effective method for the treatment of the majority of cervical pregnancies before 12 weeks gestation, and has not been shown to have detrimental effects on subsequent reproductive capacities, obstetric outcomes and progeny health for those cases with successful preservation of the uterus (Kung, Fu-Tsai, et al., 1997). When uncontrolled haemorrhage occurs, uterine artery ligation, bilateral hypogastric artery ligation, intracervical tamponade has to be performed, but sometimes because the bleeding a hysterectomy is needed. However, diagnosis of cervical pregnancy is commonly delayed and is often made intra operatively in the presence of massive blood loss, necessitating an emergency hysterectomy in $\sim 50 \%$ of cases (Palazzetti, Cipriano, Spera, Aboullkilair, Pachi, 1997).

The most common symptom described in the literature is excessive first trimester vaginal bleeding, but in our case the main symptom was an increasing colic abdominal pain with some vaginal bleeding following a painless short period of amenorrhea with no blood tests and ultrasound changes to methotrexate that required hysterectomy as the unique surgical alternative supported on her multiparous condition.

\section{CONCLUSION}

Although Cervical Ectopic Pregnancy is a rare condition that can be lifethreatening if not diagnosed and treated early, increased number of cases are being reported because of risk factors like high cesarean section rate and increased use of assisted reproductive technique for the management of infertility. The successful treatment depends on the prompt diagnosis by early physical exploration, ultrasound and B-HCG test, which can reduce the chances of severe hemorrhage necessitating hysterectomy surgery; but in cases of multiparity and previous cesarean section, hysterectomy is the most viable solution. 


\section{REFERENCES}

Fedorcsák P, Storeng R, Dale PO, Tanbo T, Abyholm T. 2000. Obesity is a risk factor for early pregnancy loss after IVF or ICSI. Acta Obstet Gynecol Scand. 2000; 79(1):43-48.

Grimes DA. 2006. Estimation of pregnancy-related mortality risk by pregnancy outcome, United States, 1991 to 1999. Am J Obstet Gynecol. Jan; 194(1):92-4. DOI 10.1016/j.ajog.2005.06.070

Hofmann HM, Urdl W, Höfler H, Hönigl W, Tamussino K. 1987. Cervical pregnancy: case reports and current concepts in diagnosis and treatment. Arch Gynecol Obstet. 241:63-69.

Kung, Fu-Tsai, et al. 1997. Subsequent reproduction and obstetric outcome after methotrexate treatment of cervical pregnancy: a review of original literature and international collaborative follow-up. Human Reproduction. 12(3):591-595.

Kuzmar I, Cortés E, Rizo M. 2014. Age group, menarche and regularity of menstrual cycles as efficiency predictors in the treatment of overweight. Nutr Hosp. 31(2): 637-641. DOI 10.3305/nh.2015.31.2.7501

Palazzetti, P., Cipriano, L., Spera, G., Aboullkilair, M., Pachi, A. 1997. Hysterectomy in women with cervical pregnancy complicated by life threatening bleeding: A case report. Clin Exp Obstet Gynecol. 24(2):74-75.

Perkins KM, Boulet SL, Kissin DM, Jamieson DJ, the National ART Surveillance (NASS) Group. 2015. Risk of Ectopic Pregnancy Associated With Assisted Reproductive Technology in the United States, 2001-2011. Obstet Gynecol. 125(1):70-78.

DOI 10.1097/AOG.0000000000000584

Pyrgiotis, E., Sultan, K., Neal, G., Hung-Ching, L., Grifo, J., Rosenwaks, Z. 1994. Ectopic pregnancies after in vitro fertilization and embryo transfer. $J$ Assist Reprod Genet. 11:79. DOI 10.1007/BF02215992

Raskin, M. 1978. Diagnosis of cervical pregnancy by ultrasound: A case report. Am J Obstet Gynecol. 130:234-235.

Sharma A., Ojha R., Mondal S., Chattopadhyay S., Sengupta P. 2013. Cervical intramural pregnancy: Report of a rare case. Niger Med J. 54:271-273.

Singh S. 2013. Diagnosis and management of cervical ectopic pregnancy. 2013. J Hum Reprod Sci. 6(4):273-276. DOI 10.4103/0974- 1208.126312.

Stratoudakis, G., Zygouris, D., Kastrinakis, K., Daskalakis, G., Panagopoulos, P. 2015. Cervical Pregnancy: A case report. HJOG. 14(1). 